\title{
ASYMMETRIC VARIATIONS IN SOME SPECIES OF THE GENUS Raphignathus Dugès (ACARI: RAPHIGNATHIDAE)
}

\author{
Meryem BİNGÜL, Sibel DOĞAN*, Salih DOĞAN \\ Erzincan University, Faculty of Arts and Sciences, Department of Biology, Erzincan, TURKEY \\ *Corresponding author: e-mail: sdilkara@erzincan.edu.tr \\ Cite this article as: \\ Bingül M., Doğan S., Doğan S. 2018. Asymmetric Variations in some Species of the Genus Raphignathus Dugès (Acari: Raphignathidae). Trakya Univ \\ J Nat Sci, 19(1) 55-58, DOI: 10.23902/trkjnat.346537
}

Received: 11 August 2017, Accepted: 13 February 2018, Online First: 27 February 2018, Published: 15 April 2018

\begin{abstract}
In this study, asymmetric variations in dorsal and ventral body setae in some adult females in three species of the genus Raphignathus Dugès; $R$. gracilis (Rack), R. hecmatanaensis Khanjani \& Ueckermann and R. kuznetzovi Doğan \& Ayyıldız were given and photographed. Records on asymmetric variations in Raphignathus species found in the literature were also reviewed.
\end{abstract}

Key words: Anomaly, asymmetric variation, Raphignathus, morpholology.

Özet: Bu çalışmada, Raphignathus Dugès cinsine ait $R$. gracilis (Rack), $R$. hecmatanaensis Khanjani \& Ueckermann ve $R$. kuznetzovi Doğan \& Ayyıldız türlerinin bazı dişilerinde görülen sırt ve karın kıllarındaki asimetrik varyasyonlar verilmiş ve fotoğrafları alınmıştır. Ayrıca, literatürde geçen Raphignathus türleriyle ilgili asimetrik varyasyon kayıtları gözden geçirilmiştir.

\section{Introduction}

The mites show a variety of morphological variations, as in other living organisms, among which variations in the form of unilateral or bilateral absences of exoskeletal structures are very common, resulting in asymmetrical individuals. Asymmetric variations can be considered as the deviations from symmetry in bilaterally paired structures and are called as anomalies. Morphological variations in mites are inevitable results of a series of changes in genetic structures and ecological changes occurring in the environments. Considering that fact that asymmetric anomalies of taxonomically important structures may cause taxonomic errors, taxonomists should have more knowledge about morphological anomalies (Bingül et al. 2017a).

The genus Raphignathus Dugès has a worldwide distribution with 68 species of which 23 have been recorded from Turkey so far (Koç \& Ayyıldız 1996, Doğan 2003, Doğan \& Ayyıldız 2003, Koç \& Akyol 2004, Koç \& Kara 2005, Akyol \& Koç 2006, Akyol \& Koç 2007, Doğan 2007, Erman et al. 2007, Bagheri et al. 2013, Dönel \& Doğan 2013, Khanjani et al. 2013, Bingül et al. 2017b). Representatives of the genus are predaceous and can be found underneath tree barks and in litter, moss, lichen, soil, stored products, house dust and bird nests. They are easily recognized by the fused cheliceral bases, forming a stylophore, cervical peritremes not embedded in dorsal surface of stylophore and confluent coxae (Fan \& Zhang 2005, Dönel \& Doğan 2013).

In spite of many taxonomic and faunal works on mites of the genus Raphignathus, data on morphological variations in this group is very limited. Some asymmetric variations in only three species, Raphignathus gracilis (Rack), R. hecmatanaensis Khanjani \& Ueckermann, $R$. collegiatus Atyeo, Baker \& Crossley, of the genus were reported by Gerson (1968), Khanjani \& Ueckermann (2003), Koç \& Akyol (2004), Doğan (2006) and Akyol (2014).

During a faunal study on urban mites of Erzincan province in Turkey (Bingül 2016), asymmetric variations were observed in 13 specimens of Raphignathus gracilis, $R$. hecmatanaensis and R. kuznetzovi Doğan \& Ayyıldız. In this study, we aimed to contribute to the knowledge on anomalies observed in Raphignathus mites.

\section{Materials and Methods}

Mite specimens were collected from grass, moss, soil and litter under Pinus nigra Arnold, P. sylvestris L., Pyrus sp., Rosa canina L. and Thuja sp. during a study carried on from 2014 to 2016 on biodiversity of urban mites in Erzincan city center (Turkey). The specimens were extracted by using Berlese funnels, cleared in $60 \%$ lactic acid and mounted on microscopic slides in Hoyer's medium. Asymmetric characters of some specimens were 
determined and photographed by using Olympus BX63CBH DIC microscopes.

\section{Results}

Our microscopic investigations showed that 13 $(1.68 \%)$ of the 773 specimens investigated showed asymmetric variations. Most of the variations were determined on Raphignathus hecmatanaensis ( $\mathrm{n}=10$, $76.92 \%)$, followed by $R$. gracilis $(\mathrm{n}=2,15.38 \%)$ and $R$. kuznetzovi $(\mathrm{n}=1,7.69 \%)$. The 13 specimens of the three species differed from others by asymmetric variations in the number of their coxal setae ( $4 c)$, aggenital setae $\left(a g_{2}\right)$, genital setae $\left(g_{2}\right)$, internal pair of humeral setae $\left(c_{1}\right)$ and the location of setae $f_{1}$ (Table 1 ).

Table 1. Morphological variations in Raphignathus mites.

\begin{tabular}{|c|c|}
\hline Species & Asymmetric variations \\
\hline R. hecmatanaensis & $\begin{array}{l}1 \text { o, right seta } a g_{2} \text { is duplex (Fig. 1) } \\
2 \text { o } \text {, right genital valve bears an extra seta (Fig. 2) } \\
3 \text { oq, left genital valve bears an extra seta (Fig. 3) } \\
1 \text { o, left seta } g_{2} \text { is absent (Fig. } 4 \text { ) } \\
3 \text { o } 9 \text {, right seta } f_{1} \text { located on striated integument (Fig. 5) }\end{array}$ \\
\hline R. gracilis & 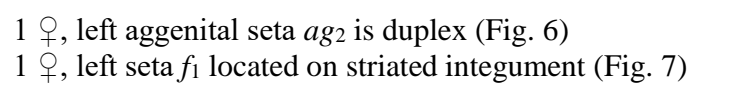 \\
\hline R. kuznetzovi & 1 , left seta $c_{1}$ and left seta $4 c$ are absent (Figs 8 and 9) \\
\hline
\end{tabular}

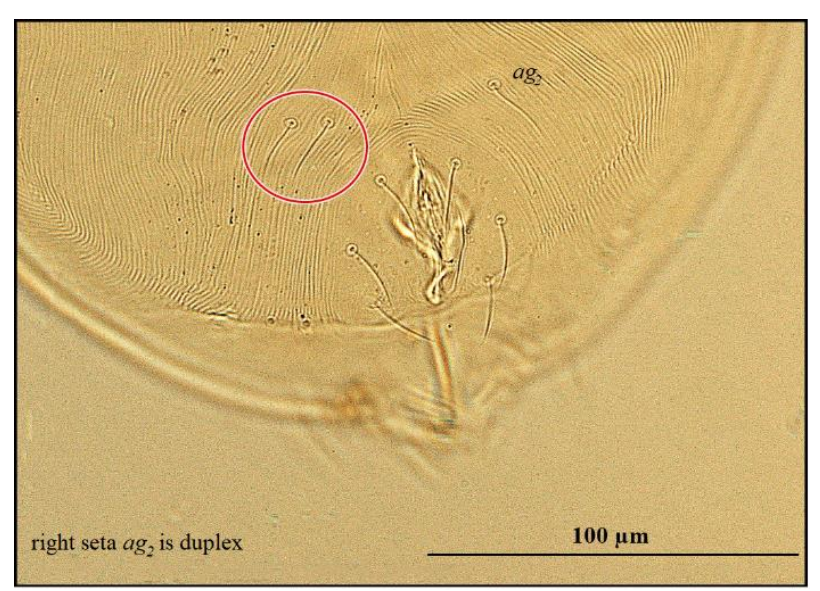

Fig. 1. Raphignathus hecmatanaensis (female): variation in the number of aggenital setae.

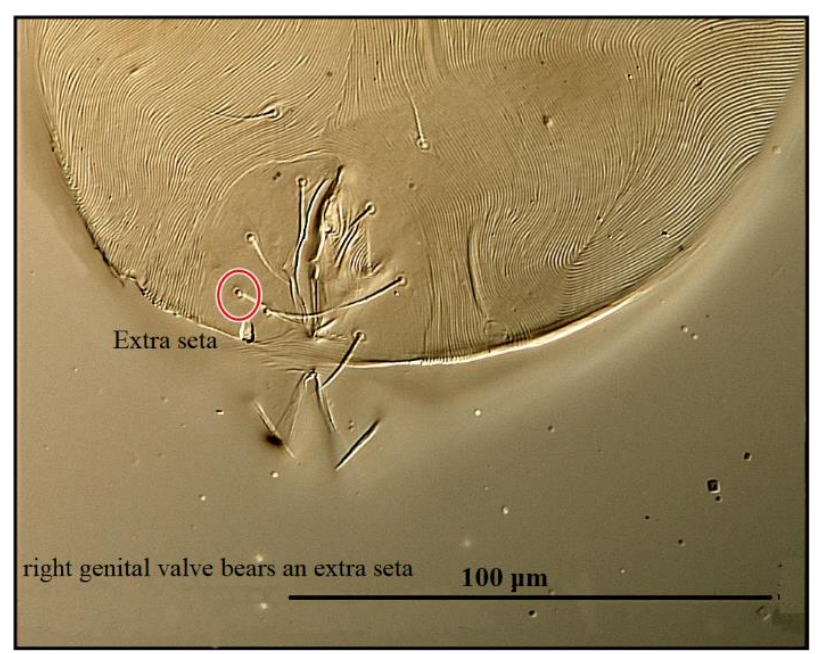

Fig. 2. Raphignathus hecmatanaensis (female): variation in the number of genital setae.

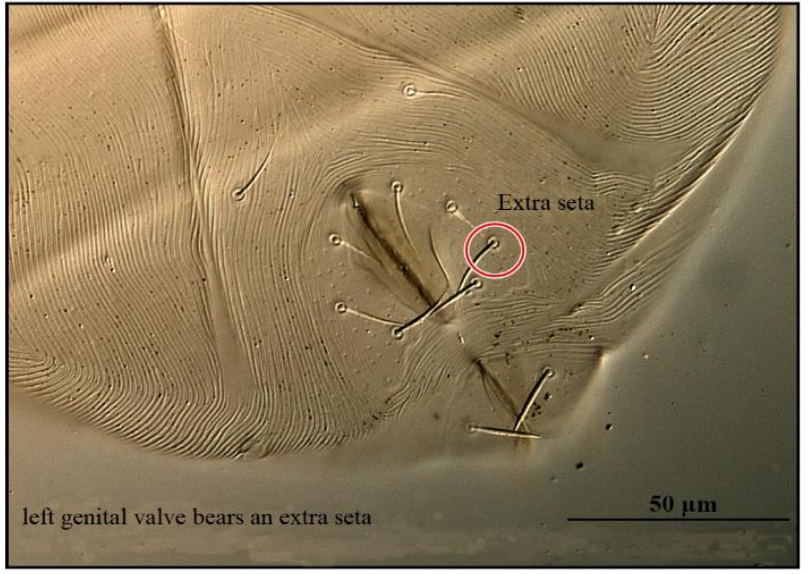

Fig. 3. Raphignathus hecmatanaensis (female): variation in the number of genital setae.

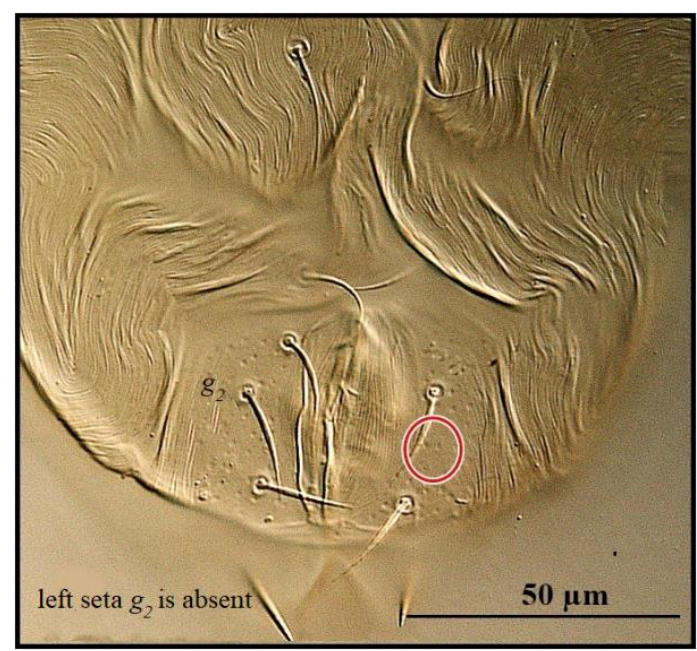

Fig. 4. Raphignathus hecmatanaensis (female): variation in the number of genital setae. 


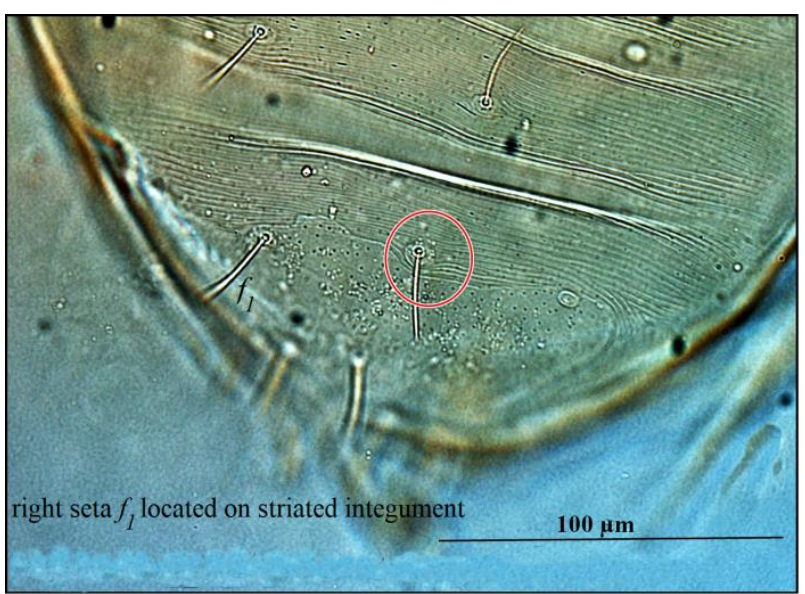

Fig. 5. Raphignathus hecmatanaensis (female): variation in the location of setae $f_{1}$

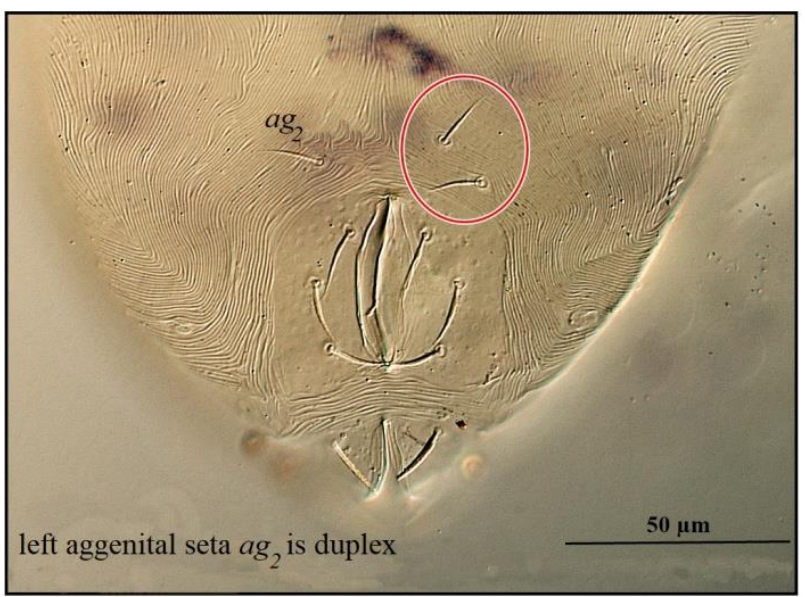

Fig. 6. Raphignathus gracilis (female): variation in the number of aggenital setae.

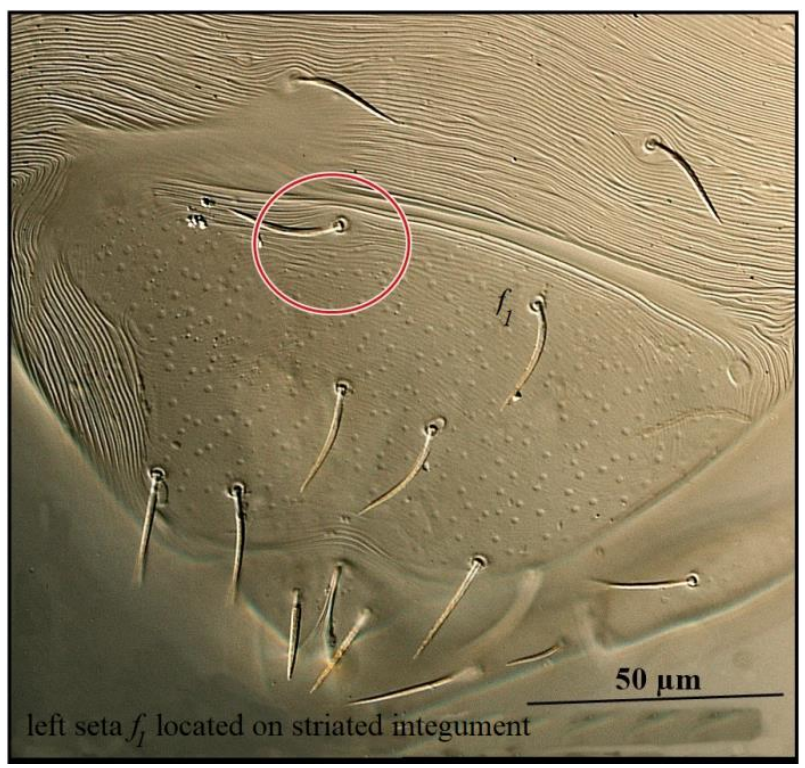

Fig. 7. Raphignathus gracilis (female): variation in the location of setae $f_{1}$

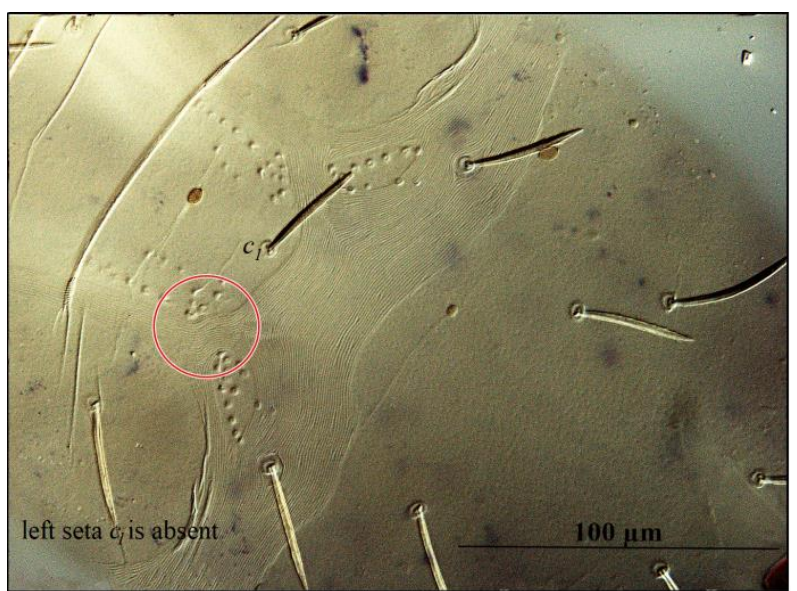

Fig. 8. Raphignathus kuznetzovi (female): variation in the number of setae $c 1$

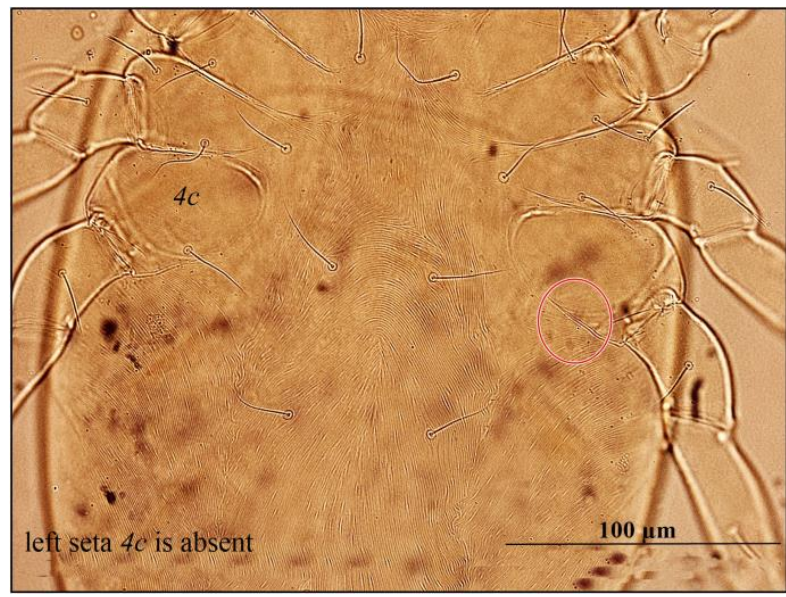

Fig. 9. Raphignathus kuznetzovi (female): variation in the number of setae $4 c$

\section{Discussion}

Some authors reported asymmetric variations in the genus Raphignathus. Gerson (1968) reported that some specimens of $R$. gracilis either had ventral aggenital setae duplicated or had four genital setae on one side. Khanjani \& Ueckermann (2003) determined variation in the number of genital setae in $R$. hecmatanaensis. The authors observed in one specimen that there were three setae on one side and four setae on other side on genital valves. Similar variations in the number of genital setae were recently reported for females of $R$. hecmatanaensis by Akyol (2014). Nine of the females Akyol (2014) investigated had 7 genital setae and one female had 5 genital setae. Koç \& Akyol (2004) reported that one adult specimen of $R$. collegiatus Atyeo, Baker \& Crossley had four genital setae on one of the genital valves while another specimen had two genital setae. Doğan (2006) reported two genital setae, instead of three, were present on the left side of holotype of $R$. ozkani Doğan.

The authors observed asymmetric variations only in the number of aggenital and genital setae in the studied mite group. Variations in the number of coxal setae $(4 c)$, 
humeral setae $\left(c_{1}\right)$ and the location of setae $f_{1}$ are reported for the first time with this study. Furthermore, asymmetric variation in $R$. kuznetzovi is reported for the first time.

Within the same faunal study (Bingül 2016) with which the current study material was collected, morphological abnormalities in some stigmaeid species were also reported by Bingül et al. (2017a). Bingül et al. (2017a) mentioned numerical variations on some body setae and differences in length and shape of some body setae in the stigmaeid species. In our observations on Raphignathus mite specimens, numerical variations were also found in some setae as in the case of stigmaeid species.

Data on asymmetric variations in Raphignathus is very limited. Observed structural changes in the present work are easily detectable variations distorting bilateral

\section{References}

1. Akyol, M. 2014. Raphignathus hecmatananensis (Acari: Raphignathidae) türünde görülen genital kıl sayısındaki morfolojik varyasyonlar. 22 $2^{\text {nd }}$ National Congress on Biology, 23-27 June, University of Eskişehir Osmangazi, Eskişehir (In Turkish).

2. Akyol, M. \& Koç, K. 2006. Raphignathus mites from Turkey (Acari: Raphignathidae). Journal of Natural History, 40: 1149-1165.

3. Akyol, M. \& Koç, K. 2007. Two new records of the genus Raphignathus (Acari: Actinedida) for the Turkish Fauna. Journal of Applied Biological Sciences, 1: 15-18.

4. Bagheri, M., Jafari, S. \& Saeej, S.P. 2013. A new species of the genus Raphignathus (Acari: Raphignathidae) from western Iran. Persian Journal of Acarology, 2(3): 481-486.

5. Bingül, M. 2016. An evaluation in terms of urban biodiversity: Erzincan urban mites. Erzincan University, Graduate School of Natural and Applied Sciences, MSc thesis, $145 \mathrm{p}$.

6. Bingül, M., Doğan, S. \& Doğan, S. 2017a. Morphological abnormalities in some stigmaeid species of Eustigmaeus, Stigmaeus and Storchia (Acari: Raphignathoidae: Stigmaeidae). Systematic and Applied Acarology, 22: 2119-2126.

7. Bingül, M., Doğan, S. \& Dilkaraoğlu, S. $2017 \mathrm{~b}$. Contributions to the knowledge of the mite genus Stigmaeus Koch (Acari: Stigmaeidae) of Turkey. European Journal of Taxonomy, 307: 1-16.

8. Doğan, S. 2003. Descriptions of three new species and two new records of Raphignathus Dugés (Acari: Raphignathidae) from Turkey. Archives des Sciences, 56: 143-153.

9. Doğan, S. 2006. Contributions to the knowledge of the raphignathoid mites of Turkey (Acari: Raphignathoidea) with description of a new species. International Journal of Acarology, 32: 371-375. symmetry. Such morphological variations, in other words anomalies, can be considered as minor changes distorting bilateral symmetry. These asymmetric variations may be induced by random environmental stresses, genetic problems during development or epigenetic changes, and are accord with the concept of fluctuating asymmetry (Bingül et al. 2017a). More detailed studies should be performed for confirmation of factors causing asymmetric variations.

\section{Acknowledgement}

This study is a part of the first author's MSc thesis, and was presented as a short summary with oral presentation at $3^{\text {rd }}$ International Symposium on EuroAsian Biodiversity (SEAB 2017), held from July 5 to 8, 2017 in Minsk, Belarus.

10. Doğan, S. 2007. Checklist of raphignathoid mites (Acari: Raphignathoidea) of Turkey. Zootaxa, 1454: 1-26.

11. Doğan, S. \& Ayyıldız, N. 2003. Mites of the genus Raphignathus (Acari: Raphignathidae) from Turkey. New Zealand Journal of Zoology, 30: 141-148.

12. Dönel, G. \& Doğan, S. 2013. Two new mite species of the genus Raphignathus Dugés (Acari: Raphignathidae) from Turkey. Turkish Journal of Zoology, 37(2): 179-183.

13. Erman, O., Özkan, M., Ayyıldız, N. \& Doğan, S. 2007. Checklist of the mites (Arachnida: Acari) of Turkey. Second supplement. Zootaxa, 1532: 1-21.

14. Gerson, U. 1968. Some raphignathoid mites from Israel. Journal of Natural History, 2: 492-537.

15. Fan, Q.-H. \& Zhang, Z.-Q. 2005. Raphignathoidea (Acari: Prostigmata). Fauna of New Zealand, Manaaki Whenua Press, Lincoln, Catenbury, New Zealand, 400 pp.

16. Khanjani, M. \& Ueckermann, E.A., 2003. Two new species of the genus Raphignathus Dugés (Acari: Raphignathidae) from Iran. Acarologia, 43: 299-306.

17. Khanjani, M., Pishavar, S. \& Mirmoayedi, A. 2013. A new species of Raphignathus Dugés (Acari: Raphignathidae) from Iran. Acarina, 21(1): 62-68.

18. Koç, K. \& Akyol, M., 2004. Favognathus afyonensis sp. nov. with notes on Raphignathus collegiatus Atyeo, Baker et Crossley, 1961 (Acari: Raphignathoidea) from Turkey. Annales Zoologici, 54: 475-479.

19. Koç, K. \& Ayy1ldız, N. 1996. Two species of Raphignathus Dugés (Acari, Prostigmata, Raphignathidae) new to the Turkish fauna. Turkish Journal of Zoology, 20: 209-214. (In Turkish).

20. Koç, K. \& Kara, M. 2005. Two new species of Raphignathoidea (Acari: Raphignathidae; Camerobiidae) from Turkey. Acarologia, 45: 195-202. 